\title{
Effects of storage time and hot weather conditions on egg qualities of two avian species
}

\author{
S. O. Olawumi* and T. S. Babatope \\ Animal Breeding and Genetics Unit, Department of Animal Production and Health Sciences, Ekiti State University, P. M. \\ B. 5363 , Ado-Ekiti, Nigeria. \\ *Corresponding author. Email: olawumisimeon@yahoo.com
}

Copyright (C) 2016 Olawumi and Babatope. This article remains permanently open access under the terms of the Creative Commons Attribution License 4.0, which permits unrestricted use, distribution, and reproduction in any medium, provided the original work is properly cited.

Received 26th June, 2016; Accepted 21st October, 2016

\begin{abstract}
The present study was conducted to determine the external and internal egg quality of Isa Brown (Gallus gallus domesticus) chicken and Japanese quails (Coturnix coturnix japonica) as affected by storage time under room temperature in the hot weather conditions of Nigeria. Parameters evaluated included egg weight, albumen and yolk indices. For each species, a total number of twenty freshly laid eggs was collected and divided into five groups representing different days of storage $(0,7,14,21$ and 28 days). Storage temperature and relative humidity respectively, are $28.3^{\circ} \mathrm{C}$ and $75 \%$. Analyzed results showed that storage time significantly affected egg weight, but has no effect on egg length and width in the two species. Egg weight at day 0 and 7 were higher and superior to 14, 21 and 28 days. Shell thickness in this study had significant decrease in values from day 0 to 28 . The decline in this trait due to prolonged storage time was probably due to loss of water as a result of evaporation from internal egg which caused loss of viscosity. With regard to albumen indices, there was a decrease in the values of albumen weight and others with increasing age of eggs in store. Pertaining to internal egg quality, Haugh unit score which measures the freshness and quality of an egg equally recorded a gradual decline from day 0 to 14, while the values fell below standard from day 14 . This implies that chicken and quail eggs are not fit for human consumption after 14 days in the hot environment unless stored in refrigerator. Yolk indices such as yolk width and height decreased with advancing age of eggs in the store. But the reverse was the case for yolk weight and ratio which recorded higher values as storage time progressed. As indicated in this study, chicken and quail eggs should not be held under room temperature for more than 14 days during hot season to maintain its freshness and quality.
\end{abstract}

Keywords: Egg qualities, Haugh unit, hot season, Isa Brown, Japanese quail, storage time.

\section{INTRODUCTION}

Avian egg serves as a means of reproduction and represents a healthy, nutritious food for humans regardless of age or sex. Chickens, quails and other species in the avian family are known to be good producers of high, quality animal proteins which are essential for mental and physical development of both adults and children. However, several factors affect the quality of food derived from eggs produced by these poultry birds. Egg quality according to Mudhar (2011) is composed of those characteristics of an egg that affects its acceptability to consumers. Thus, all precautionary measures should be taken to preserve its freshness and quality. With regard to internal egg quality characteristics, thick albumen is the major determinant. Some other vital areas determining interior egg quality are yolk index, Haugh unit and chemical composition which are calculated or analyzed in the laboratory, and the values obtained suggest to egg processing industry the suitability of the eggs for production of liquid egg, egg powder, frozen egg and yolk oil (Mudhar, 2011). Pertaining to Haugh unit, the higher the value, the better the quality of an egg, while lower values indicate egg deterioration and loss of freshness. With regard to internal egg quality traits, Orunmuyi et al. (2013) reported a significant strain differences between Black and Brown layer chickens in albumen weight, yolk weight and Haugh 
unit score. However, Kondaiah, et al. (1983) asserted that of all the egg quality traits, the Haugh unit score is considered the best objective mathematical expression to measure egg quality.

For external egg quality traits, the most important factors include smoothness, cleanliness, freshness, egg weight and shell weight. Eggs that are rough, wrinkled, dirty, soft-shelled and cracked are rejected either at the hatchery or sales point. The production of eggs together with eggshell quality is an important concern of the egg industry. According to Roland (1988), losses due to poor eggshell quality or other reasons may reach $20 \%$ before the eggs arrive at retail. Hurwitz (1989) asserted that the nutritional factors that affect eggshell quality depend on the metabolic exchanges, which occur during egg formation. A factor such as strain of chickens was reported in literature as having a significant effect on egg quality traits (Olawumi and Ogunlade, 2009). Similar results were obtained in Brown and Black layer strains by Orunmuyi et al. (2013). The researchers found significant strain differences in egg weight, egg length and width. In quails, Orhan et al. (2001) found positive effects of age of the bird on egg weight. The investigators observed that egg weight increased with the age of the quail. Some other authors reported positive effects of age of quails on the shape index (Gonzalez, 1995), albumen weight (Nazligul et al., 2001), albumen index (Nagarajan et al., 1991; Orhan et al., 2001), yolk weight (Nazligul et al., 2001; Lucas et al., 2013) and yolk index (Nagarajan et al., 1991).

While other factors affecting egg quality were given prominence in literature, the storage effect on egg quality traits is very rare. It is believed that both external and internal egg quality traits can be significantly influenced by the storage time. With longer storage time, an unfavourable physicochemical changes occur in an egg (Jones and Musgrove, 2005; Samli et al., 2005). Yilmaz and Bozkurt (2009) documented that in hens, eggs stored for more than 10 days recorded lower values in white and yolk indices and Haugh units in comparison to freshly laid eggs. Similar results were obtained in pheasants (Phasianus colchicus) by Demirel and Kirikci (2009). The authors observed that eggs stored for 1 to 2 days had higher values in white and yolk indices and Haugh units than those examined on the 9 to 10th day of storage. On the contrary, in rock partridge (Alectorus graeca), Cağlayan et al. (2009) found no significant differences in white indices and Haugh units between eggs analyzed in 1 to 2 days and 9 to 10 days of storage. In Japanese quails, Nowaczewski et al. (2010) reported that eggs stored 10 days recorded lower values in yolk and albumen indices than freshly laid eggs. The researchers also indicated that fresh eggs had higher Haugh units than those stored for 10 days.

The contrasting results of the above-mentioned studies motivated the authors to undertake investigations aimed at comparing the rate of deterioration of internal and external egg quality of Isa Brown chickens and Japanese quails reared in the cage and stored under similar conditions in the hot weather. The findings of this study will guide consumers and egg processing industries on the handling and storage of table eggs in order to preserve its freshness and quality.

\section{MATERIALS AND METHODS}

\section{Study Area}

The study was carried out at the Animal Breeding Unit, Teaching and Research Farm, Ekiti State University, AdoEkiti, between November to December, 2013. Ado-Ekiti is situated along latitude $7^{0} 31^{1}$ and $7^{0} 49^{1}$ North of the Equator and longitude $5^{0} 71^{1}$ and $5^{0} 27^{1}$ East of the Greenwich Meridian. The city falls under Derived Savannah zone. The city enjoys two separate seasonal periods namely, Rainy (May to October) and Dry (November to April) seasons.

\section{Management of Experimental birds}

Isa Brown layers and Japanese quails used for this study were reared inside cages. Isa Brown birds were about 30 weeks old, while quail birds were about 12 weeks old at the time of data collection. The birds were raised under similar nutritional status, uniform management and environmental conditions. They were given commercial layers mash containing $16 \% \mathrm{CP}$ and $2600 \mathrm{Kcal} / \mathrm{kg} \mathrm{ME}$ throughout the laying period. Feed and water were supplied ad libitum.

\section{Data collection}

Twenty freshly laid eggs were collected from each of the two species, numbered and labeled accordingly. The eggs were put in paper egg trays and transferred to a well ventilated room where analysis was carried out. The eggs per species were divided into five replicates representing different storage periods of $0,7,14,21$ and 28th day, that is, four eggs per storage time. The eggs for 0 day were analyzed immediately after collection, while the rest were stored under room temperature which ranged from 28.3 to $31^{\circ} \mathrm{C}$ and relative humidity ranged from 75 to $80 \%$.

Egg weight was measured using a 0.01 sensitive digital scale, while the length and width of egg were measured with digital Vernier caliper. After taken the external measurements of the eggs, the sharp end was carefully broken and the contents poured into flat plate in order to measure albumen and yolk indices. The yolk is then carefully separated from the albumen and placed on the scale for weighing. The plate was wiped dry after each 
Table 1. Descriptive statistics showing external and internal egg qualities of Isa Brown and Quail birds (values in parenthesis).

\begin{tabular}{|c|c|c|c|c|c|}
\hline Traits & Min. & Max. & Mean & SD & CV \\
\hline Egg weight (g) & $\begin{array}{l}59.0 \\
(9.0)\end{array}$ & $\begin{array}{c}69.0 \\
(11.0)\end{array}$ & $\begin{array}{l}65.25 \\
(10.0)\end{array}$ & $\begin{array}{c}4.35 \\
(0.82)\end{array}$ & $\begin{array}{c}6.67 \\
(8.16)\end{array}$ \\
\hline Egg length $(\mathrm{cm})$ & $\begin{array}{c}5.80 \\
(3.10)\end{array}$ & $\begin{array}{c}6.50 \\
(3.60)\end{array}$ & $\begin{array}{c}6.10 \\
(3.35)\end{array}$ & $\begin{array}{c}0.29 \\
(0.24)\end{array}$ & $\begin{array}{c}4.83 \\
(7.11)\end{array}$ \\
\hline Egg width $(\mathrm{cm})$ & $\begin{array}{c}4.70 \\
(2.40)\end{array}$ & $\begin{array}{c}5.0 \\
(2.90)\end{array}$ & $\begin{array}{c}4.88 \\
(2.55)\end{array}$ & $\begin{array}{c}0.15 \\
(0.24)\end{array}$ & $\begin{array}{c}3.08 \\
(9.34)\end{array}$ \\
\hline Albumen weight (g) & $\begin{array}{l}37.0 \\
(5.0)\end{array}$ & $\begin{array}{l}44.0 \\
(6.0)\end{array}$ & $\begin{array}{c}41.50 \\
(5.5)\end{array}$ & $\begin{array}{c}3.11 \\
(0.58)\end{array}$ & $\begin{array}{c}7.49 \\
(10.50)\end{array}$ \\
\hline Albumen height $(\mathrm{cm})$ & $\begin{array}{l}1.80 \\
(1.0)\end{array}$ & $\begin{array}{l}2.20 \\
1.10\end{array}$ & $\begin{array}{c}1.93 \\
(1.08)\end{array}$ & $\begin{array}{c}1.89 \\
(0.50)\end{array}$ & $\begin{array}{c}9.83 \\
(4.65)\end{array}$ \\
\hline Albumen width $(\mathrm{cm})$ & $\begin{array}{c}6.60 \\
(2.70)\end{array}$ & $\begin{array}{c}7.20 \\
(3.20)\end{array}$ & $\begin{array}{c}6.95 \\
(3.08)\end{array}$ & $\begin{array}{c}0.30 \\
(0.25)\end{array}$ & $\begin{array}{c}4.32 \\
(8.13)\end{array}$ \\
\hline Albumen ratio (\%) & $\begin{array}{c}62.69 \\
(50)\end{array}$ & $\begin{array}{c}65.15 \\
(60)\end{array}$ & $\begin{array}{c}63.58 \\
(55.03)\end{array}$ & $\begin{array}{c}1.16 \\
(4.10)\end{array}$ & $\begin{array}{l}1.83 \\
7.46\end{array}$ \\
\hline Yolk weight (g) & $\begin{array}{l}16.0 \\
(3.0)\end{array}$ & $\begin{array}{l}17.0 \\
(4.0)\end{array}$ & $\begin{array}{l}16.65 \\
(3.50)\end{array}$ & $\begin{array}{c}0.58 \\
(0.58)\end{array}$ & $\begin{array}{c}3.50 \\
(16.50)\end{array}$ \\
\hline Yolk height (cm) & $\begin{array}{c}2.30 \\
(1.40)\end{array}$ & $\begin{array}{c}2.50 \\
(1.80)\end{array}$ & $\begin{array}{c}2.35 \\
(1.60)\end{array}$ & $\begin{array}{c}0.10 \\
(0.23)\end{array}$ & $\begin{array}{c}4.26 \\
(14.43)\end{array}$ \\
\hline Yolk width $(\mathrm{cm})$ & $\begin{array}{c}4.10 \\
(2.10)\end{array}$ & $\begin{array}{c}4.50 \\
(2.60)\end{array}$ & $\begin{array}{c}4.28 \\
(2.35)\end{array}$ & $\begin{array}{c}0.21 \\
(0.21)\end{array}$ & $\begin{array}{c}4.82 \\
(8.86)\end{array}$ \\
\hline Yolk ratio (\%) & $\begin{array}{c}24.24 \\
(30)\end{array}$ & $\begin{array}{c}27.12 \\
(40)\end{array}$ & $\begin{array}{c}25.34 \\
(34.92)\end{array}$ & $\begin{array}{c}1.27 \\
(4.27)\end{array}$ & $\begin{array}{c}5.03 \\
(12.22)\end{array}$ \\
\hline Shell weight (g) & $\begin{array}{c}6.0 \\
(1.0)\end{array}$ & $\begin{array}{c}8.0 \\
(1.0)\end{array}$ & $\begin{array}{l}7.25 \\
(1.0)\end{array}$ & $\begin{array}{c}0.96 \\
(0)\end{array}$ & $\begin{array}{c}13.21 \\
(0)\end{array}$ \\
\hline Shell thickness (cm) & $\begin{array}{c}0.20 \\
(0.10)\end{array}$ & $\begin{array}{c}0.40 \\
(0.10)\end{array}$ & $\begin{array}{c}0.33 \\
(0.10)\end{array}$ & $\begin{array}{c}0.10 \\
(0)\end{array}$ & $\begin{array}{c}29.46 \\
(0)\end{array}$ \\
\hline Shell ratio (\%) & $\begin{array}{l}10.17 \\
(9.10)\end{array}$ & $\begin{array}{c}11-94 \\
(11.11)\end{array}$ & $\begin{array}{c}11.08 \\
(10.08)\end{array}$ & $\begin{array}{c}0.83 \\
(0.82)\end{array}$ & $\begin{array}{c}7.46 \\
(8.19)\end{array}$ \\
\hline Haugh unit (HU) & $\begin{array}{c}124 \\
(113.31) \\
\end{array}$ & $\begin{array}{c}133.09 \\
(116.84) \\
\end{array}$ & $\begin{array}{c}127.38 \\
(115.62) \\
\end{array}$ & $\begin{array}{c}3.95 \\
(1.59) \\
\end{array}$ & $\begin{array}{c}3.10 \\
(1.37) \\
\end{array}$ \\
\hline
\end{tabular}

Values in parenthesis represent analysis of quail eggs. SD, Standard Deviation, CV, Coefficient of variation.

weighing. The shell weight with membrane was obtained by carefully placing the material on the sensitivity scale, while the thickness of the shell without membrane was measured using digital Vernier caliper. Other egg quality traits were obtained by mathematical calculations, and these include:

Albumen weight $=$ egg weight $-($ yolk weight + shell weight)

Albumen ratio $=($ albumen weight/egg weight $) \times 100$

Yolk ratio $=($ yolk weight/egg weight $) \times 100$

Shell ratio $=($ shell weight/egg weight $) \times 100$

Haugh unit $($ Haugh, 1937 $)=100 \log \left(H+7.57-1.7 W^{0.37}\right)$

Where $\mathrm{H}=$ albumen height $(\mathrm{mm})$ and $\mathrm{W}=$ weight of egg (g)

\section{Statistical analysis}

Data collected were subjected to T-test with the assistance of SAS (2001) package. Mean values as well as the standard errors of the mean were calculated for all traits. The differences between storage periods in each species with regard to both internal and external egg qualities were determined by employing the one-way linear model below.

The appropriate statistical model was used:

$Y_{i k}=\mu+S_{i}+\varepsilon_{i k}$

$Y_{j k}=$ observation of the $k^{\text {th }}$ population of the $i^{\text {th }}$ storage

$\mu=$ common mean

$\mathrm{S}_{\mathrm{i}}=$ fixed effect of $\mathrm{i}^{\text {th }}$ storage time $(\mathrm{i}=5)$

$\varepsilon_{\mathrm{ik}}=$ random error

\section{RESULTS AND DISCUSSION}

Table 1 showed the descriptive statistics of external and internal egg qualities of Isa Brown and Japanese quail birds. The coefficient of variation (CV) for most traits in Isa Brown was less than $10 \%$ with the exception of shell weight and thickness. And in quails, only yolk weight, height and ratio recorded a higher than $10 \% \mathrm{CV}$. 
Table 2. Least square means showing storage time effect on external egg qualities of Isa Brown and Quail birds.

\begin{tabular}{|c|c|c|c|c|c|c|c|c|c|c|}
\hline \multirow{3}{*}{ Traits } & \multicolumn{10}{|c|}{ Storage Periods (Days) } \\
\hline & \multicolumn{5}{|c|}{ Quail eggs } & \multicolumn{5}{|c|}{ Isa Brown eggs } \\
\hline & 0 & 7 & 14 & 21 & 28 & 0 & 7 & 14 & 21 & 28 \\
\hline Egg weight (g) & $\begin{array}{l}10^{\mathrm{ab}} \\
(0.40)\end{array}$ & $\begin{array}{l}11^{\mathrm{a}} \\
(0.40)\end{array}$ & $\begin{array}{l}9.75^{\mathrm{b}} \\
(0.40)\end{array}$ & $\begin{array}{l}9.75^{b} \\
(0.40)\end{array}$ & $\begin{array}{l}9.75^{\mathrm{b}} \\
(0.40)\end{array}$ & $\begin{array}{l}65.25^{a} \\
(1.94)\end{array}$ & $\begin{array}{l}60.5^{\mathrm{ab}} \\
(1.94)\end{array}$ & $\begin{array}{l}57.25^{b} \\
(1.94)\end{array}$ & $\begin{array}{l}57.75^{b} \\
(1.94)\end{array}$ & $\begin{array}{l}57.75^{b} \\
(1.94)\end{array}$ \\
\hline Egg length $(\mathrm{cm})$ & $\begin{array}{l}3.50 \\
(0.16)\end{array}$ & $\begin{array}{l}3.30 \\
(0.16)\end{array}$ & $\begin{array}{l}3.53 \\
(0.16)\end{array}$ & $\begin{array}{l}3.60 \\
(0.16)\end{array}$ & $\begin{array}{l}3.43 \\
(0.16)\end{array}$ & $\begin{array}{l}6.10 \\
(0.15)\end{array}$ & $\begin{array}{l}5.95 \\
(0.15)\end{array}$ & $\begin{array}{l}6.0 \\
(0.15)\end{array}$ & $\begin{array}{l}5.80 \\
(0.15)\end{array}$ & $\begin{array}{l}6.18 \\
(0.15)\end{array}$ \\
\hline Egg width $(\mathrm{cm})$ & $\begin{array}{l}2.55 \\
(0.11)\end{array}$ & $\begin{array}{l}2.68 \\
(0.11)\end{array}$ & $\begin{array}{l}2.73 \\
(0.11)\end{array}$ & $\begin{array}{l}2.83 \\
(0.11)\end{array}$ & $\begin{array}{l}2.73 \\
(0.11)\end{array}$ & $\begin{array}{l}4.88 \\
(0.13)\end{array}$ & $\begin{array}{l}4.58 \\
(0.13)\end{array}$ & $\begin{array}{l}4.58 \\
(0.13)\end{array}$ & $\begin{array}{l}4.58 \\
(0.13)\end{array}$ & $\begin{array}{l}4.58 \\
(0.13)\end{array}$ \\
\hline Shell weight $(\mathrm{g})$ & $\begin{array}{l}1.00^{c} \\
(0.16)\end{array}$ & $\begin{array}{l}1.25^{b c} \\
(0.11)\end{array}$ & $\begin{array}{l}1.00^{c} \\
(0.11)\end{array}$ & $\begin{array}{l}2.25^{\mathrm{a}} \\
(0.11)\end{array}$ & $\begin{array}{l}1.75^{\mathrm{ab}} \\
(0.11)\end{array}$ & $\begin{array}{l}7.25^{\mathrm{a}} \\
(0.36)\end{array}$ & $\begin{array}{l}6.0^{\mathrm{b}} \\
(0.36)\end{array}$ & $\begin{array}{l}6.75^{a b} \\
(0.36)\end{array}$ & $\begin{array}{l}7.5^{a} \\
(0.36)\end{array}$ & $\begin{array}{l}6.0^{\mathrm{b}} \\
(0.36)\end{array}$ \\
\hline Shell thickness $(\mathrm{cm})$ & $\begin{array}{l}0.10^{\mathrm{a}} \\
(0.003)\end{array}$ & $\begin{array}{l}0.09^{b} \\
(0.003)\end{array}$ & $\begin{array}{l}0.08^{\mathrm{bc}} \\
(0.003)\end{array}$ & $\begin{array}{l}0.08^{b c} \\
(0.003)\end{array}$ & $\begin{array}{l}0.07^{c} \\
(0.003)\end{array}$ & $\begin{array}{l}0.33^{\mathrm{a}} \\
(0.03)\end{array}$ & $\begin{array}{l}0.33^{\mathrm{a}} \\
(0.03)\end{array}$ & $\begin{array}{l}0.24^{\mathrm{ab}} \\
(0.03)\end{array}$ & $\begin{array}{l}0.20^{\mathrm{b}} \\
(0.03)\end{array}$ & $\begin{array}{l}0.20^{\mathrm{b}} \\
(0.03)\end{array}$ \\
\hline Shell ratio $(\%)$ & $\begin{array}{l}10.05^{b} \\
(1.71)\end{array}$ & $\begin{array}{l}11.63^{b} \\
(1.71)\end{array}$ & $\begin{array}{l}10.33^{b} \\
(1.71)\end{array}$ & $\begin{array}{l}23.06^{a} \\
(1.71)\end{array}$ & $\begin{array}{l}18.06^{a} \\
(1.71)\end{array}$ & $\begin{array}{l}11.08^{\mathrm{bc}} \\
(0.41)\end{array}$ & $\begin{array}{l}9.94^{c} \\
(0.41)\end{array}$ & $\begin{array}{l}11.75^{\mathrm{ab}} \\
(0.41)\end{array}$ & $\begin{array}{l}12.98^{\mathrm{a}} \\
(0.41)\end{array}$ & $\begin{array}{l}10.44^{c} \\
(0.41)\end{array}$ \\
\hline
\end{tabular}

Values in parenthesis represent standard errors. abc - means along rows for each specie with different superscripts are significantly different $(\mathrm{P}<0.01)$.

Mean values determined for external and internal egg qualities of Isa Brown and Japanese quail birds were presented in Table 2. In both species, external egg indices were significantly $(P<0.01)$ affected by storage time except egg length and width. In Isa Brown, egg weight decreased in mean values with progressive storage time and similar results were recorded for Japanese quail. The decreasing value in egg weight with storage time may be as a result of loss of water through the pores of the eggs since they were stored under room temperature during the hot weather conditions. Nowaczewski et al. (2010) equally reported that quail egg weight decreased with increasing storage time. Pertaining to shell indices, there was significant $(P<0.01)$ effect of storage time on shell weight, thickness and ratio in both species. It was revealed in this study that the quality of eggshell declined which resulted to lower values reported for shell thickness with increasing storage time. The fact that external egg qualities declined with increasing storage time means that the egg is now vulnerable to bacterial attack which may lead to loss of quality in egg composition as a result of entry of microorganisms through the thin shell. The results of the present study agree with the findings of Panigraphi et al. (1989) who reported that qualities of all eggs are at maximum when the eggs are freshly laid and decreased with increasing storage time.

With regard to internal egg qualities (Table 3 ), the progressive increase in storage time has adverse effect on all the albumen and yolk indices. In Isa Brown and Japanese quails, albumen weight, height, width and ratios were significantly affected. That is, the mean values for these traits declined as storage period progressed. The rate of decline was more pronounced in Isa Brown eggs than Japanese quails. This implies that chicken eggs deteriorate faster than quail eggs when stored under room temperature during the hot season of the year. This might be due to the bigger size $(65 \mathrm{~g})$ of the chicken egg with large surface area has more air pores which evaporation took place than quail egg $(10 \mathrm{~g})$. In Isa Brown chickens, albumen white especially at 21 st and 28th day storage could not be measured as it was found to be watery, flat and of foul odour indicating loss of freshness and quality. Similar to what was reported in this study for albumen indices, yolk weight, height, width and ratios were significantly influenced by the storage time in the two species (Table 2). The mean values for these traits decreased with advancing age of eggs in storage room. The findings of Nowaczewski et al. (2010) of the storage effect on quail egg white and yolk quality was in agreement with this study. The investigators reported that egg white and yolk quality deteriorated after three days storage. Jones and Musgrove (2005) and Samli et al. (2005) opined that unfavourable physicochemical changes take place in the egg content with the lengthening of storage period. An interesting observation in this study was that yolk ratio was higher in Coturnix quail than in Isa Brown chicken. The values of yolk ratio recorded for quail egg (40.83\%) at 28th day in storage was higher than what was recorded for Isa Brown (25.34\%) on 1 st day.

After 1 day storage, the Haugh unit (Table 3) decreased gradually in both species, but the deterioration was more pronounced in chicken egg than quail. At 14th day storage, Isa Brown egg was still good for consumption judging from the value (HU-103.84) obtained, but unfit for human consumption thereafter. Pertaining to quail egg, $\mathrm{HU}$ was higher than standard (Grade A egg: $\mathrm{HU}=70$; North, 1978) for fresh egg from 1 to 14th day but declined in value thereafter. From 14th day onwards, HU scores 
Table 3. Least square means showing storage time effect on internal egg qualities of Isa Brown and Quail birds.

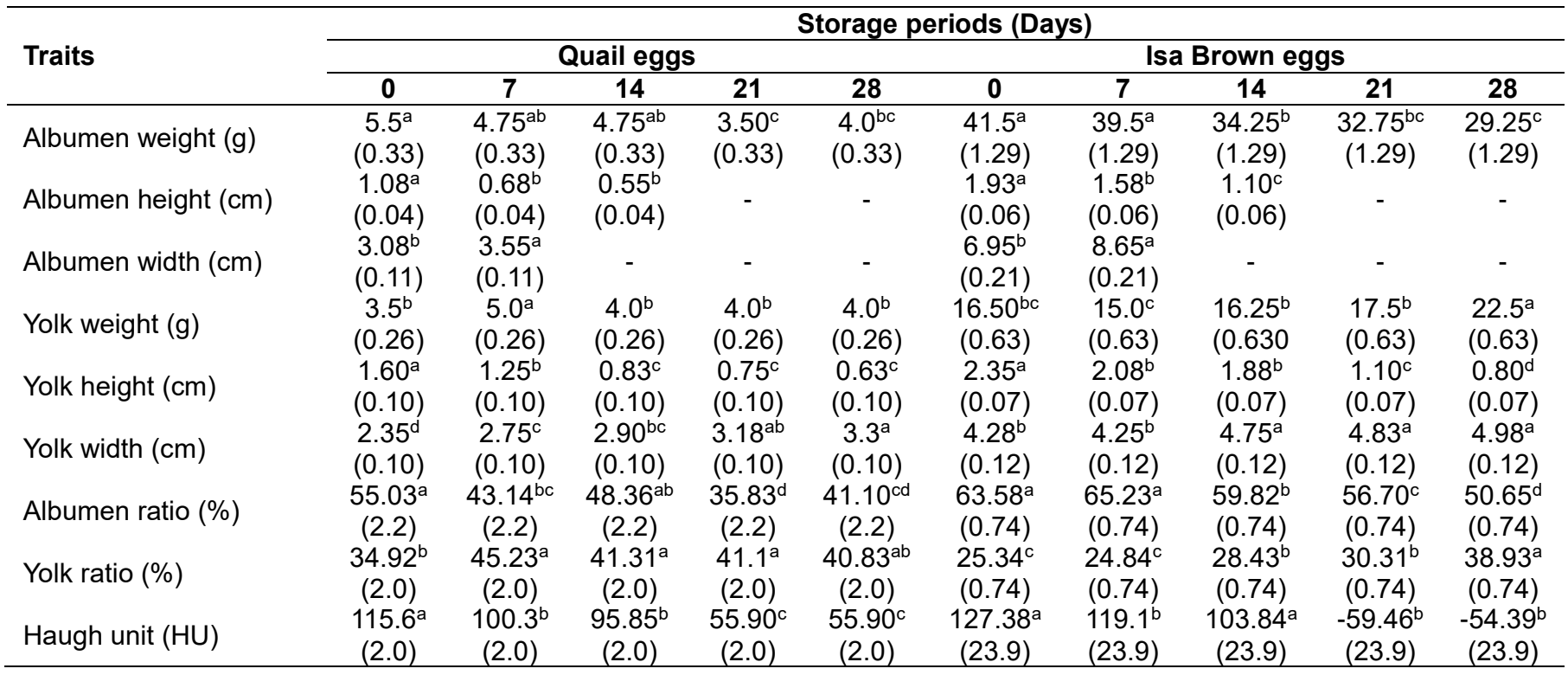

Values in parenthesis represent standard errors. (-) represent where egg internal quality became flat and watery. abcd, means along rows for each specie with different superscripts are significantly different $(P<0.01)$.

for both Isa Brown and quail eggs were very low when compared to what a quality egg should have. In the former, $\mathrm{HU}$ recorded negative mean values $(-59.46$ and 54.39), respectively at 21 st and 28th day storage. This implies that unless kept in the refrigerator eating Isa Brown chicken egg after 14th day storage will amount to consuming unhygienic, unhealthy animal proteins. And this will be more damaging to human health than not eating egg at all. The result of this study was comparable with Akyurek and Okur (2009) who found that HU decreased in eggs as storage time progressed. In agreement also with the present study, Tilki and Saatci (2004) in Rock partridges observed deterioration in quality of albumen white when eggs were stored for varying number of days (7 to 14 days). However, the findings of Demirel and Kirikçi (2009) contradicted the HU values reported in this study. The authors observed no significant deterioration of white egg quality in Pheasant eggs stored for 1 to 8 days. The differences between the present study and previous studies with respect to the storage effect on albumen white and $\mathrm{HU}$ might be due to differences in storage time and temperature, strain of quail and chicken, feed quality, location and geographical zone.

\section{Conclusion}

This study revealed that Isa Brown egg deteriorated in quality faster and more than Japanese quail egg as storage period progressed. This deterioration could be attributed to decline in shell quality as a result of loss of water through evaporation from shell pores as storage time progressed. Isa Brown egg with large surface area recorded greater water loss and poor internal egg quality than Japanese quail egg. It was also found that $\mathrm{HU}, \mathrm{a}$ determinant of egg quality was influenced by storage time. The rate of deterioration was more pronounced with Isa Brown chicken egg than Japanese quail egg. In both species, HU scores were below the minimum standard value after 14 day storage time. This implies that quail and chicken eggs are not good and healthy for consumption after this period.

\section{CONFLICT OF INTEREST}

The authors declare that they have no conflict of interest.

\section{REFERENCES}

Akyurek, H., \& Okur, A. A. (2009). Effect of storage time, temperature and hen age on egg quality in free-range layer hens. Journal Animal Veterinary advances, 8, 1953-1958.

Cağlayan, T., Alaşahan, S., Kirikçi, K., \& Günlü, A. (2009). Effect of different egg storage periods on some egg quality characteristics and hatchability of patridges (Alectorus graeca). Poultry Science, 88, 1330-1333.

Demirel, S., \& Kirikçi, K. (2009). Effect of different storage times on some egg quality characteristics and hatchability of pheasants (Phasianus colchicus). Poultry Science, 88, 440-444.

Gonzalez, M. (1995). Influence of age on physical traits of Japanese quails (Coturnix coturnix japonica) eggs. Ann. Zootech., 44, 307-312. 
Haugh, R. R. (1937). The Haugh unit for measuring egg quality. US Poultry Mag., 43, 552-573.

Hurwitz, S. (1989).Calcium homeostasis in birds. Vitamins and Hormones, 45, 173-221.

Jones, D. R., \& Musgrove, M. T. (2005). Effects of extended storage on egg quality factors. Poultry Science, 84, 17741777.

Kondaiah, N., Panda, B., \& Singhal, R. A. (1983).Internal egg quality measure for quail eggs. Indian Journal of Animal Science, 53, 1261-1264.

Lucáš, Z., Zdeněk, L., \& Ludmila, K. (2013). The effect of the age of Japanese quails on certain egg quality traits and their relationship. Veterinarski Arhiv, 83(2), 223-232.

Mudhar, A. S. A. T. (2011). Evaluation of some external and internal egg quality traits of quails reared in Basrah city. Basrah Journal of Veterinary Research, 10(2), 78-84.

Nagarajan, S., Narahari, D., Jayaprasad, I. A., \& Thyagarajan, D. (1991). Influence of stocking density and layer age on production traits and egg quality in Japanese quail. British Poultry Science, 32, 243-248.

Nazligul, A., Turkyilmax, K., \& Bardkçioglu, H. E. (2001).A study on some production traits and egg quality characteristics of Japanese quail. Turk. J. Vet Anim. Sci., 25, 1007-1013.

North, O. M. (1978). Commercial Chick Production Manual, $3^{\text {rd }}$ edition. The Avi Publishing Company. Inc. Westport, Connecticut. p. 84.

Nowaczewski, S., Kontecka, H., Rosiñski, A., Koberling, S., \& Koronowski, P. (2010). Egg quality of Japanese quail depends on layer age and storage time. Folia biologica, 58, 201-207.

Olawumi, S. O., \& Ogunlade, J. T. (2009). The effects of genotype and age of layer Breeders on egg quality traits. Nigerian Journal of Animal Production, 36(2), 228-236.
Orhan, H., Erensayin, C., \& Aktan, S. (2001). Determining egg quality characteristics of Japanese quails (Coturnix coturnix japonica) at different ages. Hayvansal Üretim, 1, 44-49.

Orunmuyi, M., Okezie, O. I., Bawa, G. S., Ojo, O. A., \& Olugbemi, T. S. (2013). Comparative egg quality traits of four poultry species. Journal of Applied Agricultural Research, 5(2), 141-145.

Panigraphi, S., Plumb, V. F. \& Mantrin, D. H. (1989). Effect of dietary cotton seed meal with and without non-treatment on laying hens. British Poultry Science, 30, 641-649.

Roland, D. A. (1988). Eggshell problems: estimates of Incidence and economic impact. Poultry Science, 67, 18011803.

Samli, H. E., Agma, A., \& Senkoylu, N. (2005). Effect of storage time and temperature on egg quality in old laying hens. Journal Applied Poultry Research, 14, 548-553.

Statistical Analysis System (SAS, 2001). SAS Users Guide. Statistics, 8th edition, SAS Institute Cary,NC, USA.

Tilki, M., \& Saatci, M. (2004). Effects of storage time on external and internal characteristics in patridge (Alectoris graeca) eggs. Revue de médecine vétérinair., 155, 561-564.

Yilmaz, A. A., \& Bozkurt, Z. (2009). Effects of hen age, storage period and stretch film packaging on internal and external quality traits of table eggs. Lucrãri Ştiinţifice Zootehniesi Bitehnologii, 42, 462-469. 